Vol. 1, No. 2, pp. 183-203, (December 2020)

DOI: 10.21608 /aujes.2020.127586

Aswan University Journal of Environmental Studies (AUJES)

Online ISSN: 2735-4237, Print ISSN: 2735-4229

Journal homepage: https://aujes.journals.ekb.eg/

Original research

E-mail: AUJES@aswu.edu.eg

\title{
Adsorption of Heavy Metals on Chemically Modified Muscovite
}

\author{
M. Nageeb Rashed*, A.A. Arfien, F.A. El-Dowy \\ Chemistry Department, Faculty of Science, Aswan University, Egypt
}

Received: $28 / 8 / 2020$

Accepted: $24 / 11 / 2020$

(C) Unit of Environmental Studies and Development, Aswan University

\begin{abstract}
:
Effective adsorbent was prepared from Egyptian Muscovite by activation with $\mathrm{H}_{2} \mathrm{O}_{2}, \mathrm{HCl}$ and/or $\mathrm{H}_{2} \mathrm{O}_{2} / \mathrm{HCl}$. The prepared adsorbents were applied for the removal of cadmium and lead from polluted water. Raw Muscovite powder was activated by different treatments using 30\% $\mathrm{H}_{2} \mathrm{O}_{2}, \mathrm{HCl}$, and/or $\mathrm{HCl} / \mathrm{H}_{2} \mathrm{O}_{2}$. Optimum adsorption conditions of $\mathrm{pH}$, adsorbent dose, initial metal concentration, stirring time and solution temperature were optimized for the maximum adsorption of $\mathrm{Cd}$ and $\mathrm{Pb}$. The results reveal that the Muscovite adsorbent prepared with a mixture of $\mathrm{HCl} / \mathrm{H}_{2} \mathrm{O}_{2}$ shows the higher adsorption of $\mathrm{Cd}$ and $\mathrm{Pb}$ than that with $\mathrm{HCl}$ or $\mathrm{H}_{2} \mathrm{O}_{2}$. The maximum adsorption of $\mathrm{Cd}$ and $\mathrm{Pb}$ by the developed adsorbent was $97.8 \%$ and $98.1 \%$, respectively at $60 \mathrm{~min}, 25^{\circ} \mathrm{C}$, initial metal concentration $50 \mathrm{ppm}$, adsorbent dose $2 \mathrm{~g} / 50 \mathrm{~mL}$ solution and $\mathrm{pH} 6$ for lead and $\mathrm{pH} 7$ for cadmium. Adsorption isotherms and kinetic models were investigated and ended to that the adsorption of $\mathrm{Pb}$ and $\mathrm{Cd}$ fitted well Langmuir adsorption isotherm.
\end{abstract}

Keywords: adsorption, Muscovite, acid activation, purification, heavy metals

\section{1- INTRODUCTION}

Water pollution is one of the most serious environmental problems which is caused by a variety of human activities such as industrial, agricultural and domestic.

High concentration of heavy metals and other inorganic pollutants contaminate the water. Heavy metals are becoming more prominent due to the diverse routes of its exposure, its toxic implications across time scales and the level of industrial development in recent decades. The presence of heavy metal ions (e.g. $\mathrm{Hg}, \mathrm{Cu}, \mathrm{Cd}, \mathrm{Pb}, \mathrm{As}$, and $\mathrm{Se}$ ) in water, even at very low levels, can cause damage to ecosystem and human life, because they are not biodegradable (Badawy et al., 2010; El-Bayaa et al., 2009).

Lead and cadmium are two common toxic heavy metals that man is increasingly being exposed to due to their properties and wide applications in materials and technologies that define human survival.

Corresponding authors*: E-mail addresses: mnrashed@ hotmail.com 
High concentrations of lead is known to cause encephalopathy, cognitive impairment, kidney and liver damage, anemia and toxicity to the reproductive system (Pagliuca and Mufti, 1990; O’Connell et al.,2008; Adekunle et al., 2014).

Methods used to remove heavy metals from polluted water and wastewater include, coagulation reduction, precipitation and flotation, adsorption, ion exchange, membrane technology, electrochemical treatment, electrolysis, and membrane processes, and adsorption (Yang et al., 2010 ; Mahdavi et al., 2013). Among these technologies, adsorption has the additional advantages of applicability at very low concentrations. Natural materials such as chitosan, zeolites, clays, or certain waste products from industrial operations (such as fly ash, coal, and oxides) are classified as low-cost adsorbents compared to activated carbon (Cheira et al.,2019a,b; Shawky et al.2019; Rashed et al.2017, 2018,2019).

Clay refers to a class of materials generally made up of layered silicates or clay minerals with traces of metal oxides and organic matter. Clay minerals are widespread and abundant in aquatic and terrestrial environments and, being finely divided, have large surface areas per unit of mass (Abollino et al., 2008). Muscovite is a hydrated magnesium aluminum silicate mineral formed by weathering biotite and iron-bearing phlogopite micas. It has several advantages such as high availability, easy handling, low-cost adsorbent, and selectivity over other natural adsorbents (Katsou et al., 2011). Muscovite $\mathrm{KAl}_{2}\left[\mathrm{Si}_{3} \mathrm{AlO}_{10}(\mathrm{OH})_{2}\right]$ is one of clay mineral which belongs to mica group while quartz can be present in clay materials in lower proportion. The minerals of the mica group consist of layers of one octahedral $\mathrm{Al}(\mathrm{O} / \mathrm{OH})_{6}$-sheet sandwiched by two tetrahedral $\mathrm{SiO}_{4}$-sheets (Muazu et al.2020)

Schmidt et al. (2012) studied adsorption of tetravalent thorium to the (l0 01 1) basal surface of the phyllosilicate muscovite from an aqueous solution, and found that the uptake measurements of the adsorption to the Muscovite surface follows a Langmuir isotherm. Yang et al. (2010) reported adsorption of As (III), As(V), Cd (II), Cu (II), and Pb (II) from aqueous solutions by natural Muscovite (NM), and found that the adsorption of the metals was greatly influenced by solution $\mathrm{pH}$ but not by ionic strength. The maximum adsorption capacities of NM were 0.791, 0.750, $0.630,0.618$, and $0.330 \mathrm{mg} \mathrm{g}^{-1}$ for $\mathrm{As}(\mathrm{V}), \mathrm{Cd}$ (II), $\mathrm{Pb}$ (II), Cu (II), and As (III), respectively. Although NM is cheaper than purified muscovite, the adsorption capacities of NM are less than those of purified materials. Hamidpour et al. (2019) studied adsorption of cadmium and zinc onto Micaceous minerals (muscovite and phlogopite) the effect of hydroxamate siderophore deferoxamine B (DFOB) on cadmium (Cd) and zinc $(\mathrm{Zn})$ adsorption, and reported that the presence of DFOB diminished the adsorption of $\mathrm{Cd}$ and $\mathrm{Zn}$ onto both minerals, particularly under neutral to alkaline $\mathrm{pH}$ conditions.

This study aims to prepare an effective adsorbents from Muscovite by chemical activation with $\mathrm{H}_{2} \mathrm{O}_{2}, \mathrm{HCl}$ and/or $\mathrm{H}_{2} \mathrm{O}_{2} / \mathrm{HCl}$, and appleing the resulted adsporbents for the removal of $\mathrm{Pb}$ and $\mathrm{Cd}$ from its solution.

\section{2- MATERIALS AND METHODS}

\subsection{Chemicals and Reagents}

Standard stock solutions of $1000 \mathrm{ppm} \mathrm{Pb}$ and $\mathrm{Cd}$ ions were prepared by dissolving appropriate amounts of analytical grade reagent [cadmium nitrate tetrahydrate- $\mathrm{Cd}\left(\mathrm{NO}_{3}\right)_{2} \cdot 4 \mathrm{H}_{2} \mathrm{O}$ (SigmaAldrich) (99\% assay) and $\mathrm{Pb}\left(\mathrm{NO}_{3}\right)_{2}$ (Sigma- Aldrich) (99\% assay)] in deionized water using a $1000 \mathrm{~mL}$ volumetric flask (MBL Boro England). The stock solutions were acidified to prevent hydrolysis by adding $5 \mathrm{~mL} \mathrm{HNO}_{3}$ and the volume was made up to the $1000 \mathrm{~mL}$. 


\subsection{Characterization of activated Muscovite adsorbent}

Morphology of Muscovite and activated Muscovite adsorbent was examined using SEM, XRD and FTIR. Micromeritics Tristar 3000 (Georgia, USA) instrument, utilizing $\mathrm{N}_{2}$ (g) adsorption technique, was used to determine the surface area and porosity of Muscovite and activated Muscovite adsorbent samples.

\subsection{Sample collection}

Muscovite mineral supplied from Elhafafet area (south of east desert, Egypt) was used as raw material in this study. Muscovite samples had dark gray color. Five bulk samples $(5 \mathrm{~kg})$ were collected from the area. The samples were crushed and ground to powder with a laboratory agate mortar. The silica particles were removed from muscovite samples by contact the powdered muscovite with deionized water for one day, filtered, dried at $60^{\circ} \mathrm{c}$ for $24 \mathrm{~h}$ and, sieved to $565 \mu \mathrm{m}$. The chemical composition of Muscovite sample was detected by XRF as shown in Table 1.

Table 1.

Table (1) Chemical composition of raw Muscovite sample.

\begin{tabular}{|c|c|c|c|c|c|c|c|}
\hline $\mathbf{S i O}_{\mathbf{2}} \%$ & $\mathbf{N a}_{\mathbf{2}} \mathbf{O} \%$ & $\mathbf{K}_{\mathbf{2}} \mathbf{O} \%$ & $\mathbf{A l}_{\mathbf{2}} \mathbf{O}_{\mathbf{3}} \%$ & $\mathbf{C d} \mathbf{p p m}$ & $\mathbf{Z n} \mathbf{~ p p m}$ & $\mathbf{P b} \mathbf{~ p p m}$ & $\mathbf{C u} \mathbf{~ p p m}$ \\
\hline 48.16 & 0.72 & 10.62 & 32.5 & 12.70 & 0.482 & UD & UD \\
\hline
\end{tabular}

\subsection{Preparation of Muscovite adsorbents}

\subsubsection{Purification of Muscovite}

$10 \mathrm{~g}$ Muscovite was placed in $100 \mathrm{~mL}$ ultrapure water and sonicated for $10 \mathrm{~min}$, let the solution stand down for $10 \mathrm{~min}$ and after then separated by decantation. Repeated this step twice, filtered the solution and dried in $60^{\circ} \mathrm{C}$ for $24 \mathrm{~h}$ (Sis and Uysal,2014).

\subsubsection{Chemical activation of Muscovite}

\subsubsection{Activation with hydrochloric acid}

Activation of the muscovite was run by mixing of the purified powder muscovite with different $\mathrm{HCl}$ concentration at different times.

$5 \mathrm{gm}$ purified muscovite was mixed with $200 \mathrm{~mL} \mathrm{HCl}$ (concentration $0.5,0.8,1.5$ and $2 \mathrm{M}$ ), stirred at $25^{\circ} \mathrm{C}$ for 8,10 and $12 \mathrm{hr}$, filtered, washed with deionized water till the solution became neutral (the filtrate was tested with $\mathrm{AgNO}_{3}$ ) and dried at $100^{\circ} \mathrm{C}$ for 10 hours. All the developed adsorbents were grounded in an agate mortar and sieved to $63 \mu \mathrm{m}$ (Hashem et al, 2015). The developed activated Muscovite adsorbents were labeled (AM1-AM12)

\subsubsection{Activation with hydrogen peroxide $\mathrm{H}_{2} \mathrm{O}_{2}(30 \%)$}

Chemical activation of Muscovite with $\mathrm{H}_{2} \mathrm{O}_{2}$ was done by treatment with $30 \% \mathrm{H}_{2} \mathrm{O}_{2}$ solution. $5 \mathrm{~g}$ of purified Muscovite was stirred with $200 \mathrm{~mL} \mathrm{30 \%} \mathrm{H}_{2} \mathrm{O}_{2}$ for 6,7 and $8 \mathrm{~h}$, filtered, washed several times with deionized water, and dried in oven at $100{ }^{\circ} \mathrm{C}$ for $24 \mathrm{~h}$ (Hashem et al, 2015). All the developed adsorbents were ground in an agate mortar and sieved to $63 \mu \mathrm{m}$ (AM13AM15).

\subsubsection{Activation with mixture of hydrochloric acid and hydrogen peroxide}

2.4.2.3.1. $\mathrm{HCl} / \mathrm{H}_{2} \mathrm{O}_{2}$ (vol / vol)

$5 \mathrm{~g}$ of purified muscovite was mixed with $200 \mathrm{~mL} 0.8 \mathrm{M} \mathrm{HCl}$, stirred at $25^{\circ} \mathrm{C}$ for $10 \mathrm{hr}$, filtered, washed with deionized water till the solution became neutral (the filtrate was tested with $\mathrm{AgNO}_{3}$ ) and dried at $100^{\circ} \mathrm{C}$ for $10 \mathrm{hr}$. Then $5 \mathrm{~g}$ of acid activated muscovite (from the previous step) was 
mixed in $200 \mathrm{~mL} 30 \% \mathrm{H}_{2} \mathrm{O}_{2}$, stirred mechanically for $7 \mathrm{hr}$, filtered, washed with deionized water till the solution became neutral and dried at $100^{\circ} \mathrm{C}$ for $10 \mathrm{hr}$. The developed adsorbent was grounded in an agate mortar and sieved to $63 \mu \mathrm{m}$. The developed activated muscovite adsorbent was labeled (AM16).

\subsubsection{2. $\mathrm{HCl} / \mathrm{H}_{2} \mathrm{O}_{2}$ (wt by $\left.w t\right)$}

$2.5 \mathrm{~g}$ of activated muscovite by $0.8 \mathrm{M} \mathrm{HCl}$ for $10 \mathrm{~h}$ and $2.5 \mathrm{~g}$ of activated muscovite by $\mathrm{H}_{2} \mathrm{O}_{2}$ $(30 \%)$ for $7 \mathrm{hr}$ was mixed mechanically in an agate mortar, and sieved to $63 \mu \mathrm{m}$. The developed activated muscovite adsorbent was labeled (AM17)

\subsubsection{Selection of the best adsorbent}

For selecting the best adsorbent for the removal of $\mathrm{Pb}$ and $\mathrm{Cd}$ from its solution, the following experiments were applied

\subsubsection{Adsorption of cadmium and lead}

$0.2 \mathrm{~g}$ of each of the prepared activated muscovite samples (AM1 - AM17) was stirred with $50 \mathrm{~mL}$ of $50 \mathrm{ppm} \mathrm{Cd}^{2+}$ and $\mathrm{Pb}^{2+}$ for $2 \mathrm{hr}$ and $\mathrm{pH}$ solution was adjusted at $\mathrm{pH} 6$ using $\mathrm{HNO}_{3}$ or $\mathrm{NaOH}$ solution. The mixture was then filtered and the metal ions in the filtrate were measured by atomic absorption spectrophotometer.

\subsubsection{Batch adsorption experiments}

Batch mode experiments were done for the removal of both $\mathrm{Cd}^{2+}$ and $\mathrm{Pb}^{2+}$ ions on raw and chemically activated Muscovites. Batch adsorption experiments examined the effect of solution $\mathrm{pH}$, initial of adsobate concentration, solution temperature, adsorbent dosage, and contact time.

\subsubsection{Effect of $p H$}

Adsorption experimenters for the effect of solution $\mathrm{pH}$ on metal adsorption were conducted as follows: $0.5 \mathrm{~g}$ of the activated muscovite was stirred with $50 \mathrm{~mL}$ of $50 \mathrm{ppm}$ standard solution of single ions $\mathrm{Cd}^{2+}$ and $\mathrm{Pb}^{2+}$ for $2 \mathrm{hr}$. Solution $\mathrm{pH}$ was adjusted at 2, 4,5, 6,7,8 and 10 using $\mathrm{HNO}_{3}$ or $\mathrm{NaOH}$ solution. The mixture was then filtered and the metal ions in the filtrate were measured by atomic absorption spectrophotometer

\subsubsection{Effect of adsorbent dosage}

Different amounts $(0.5,1.0,1.5$ and $2.0 \mathrm{~g})$ of activated muscovite was stirred with $50 \mathrm{~mL}$ of 50 ppm standard solutions of single ions for $2 \mathrm{hr}$ and adjusted the $\mathrm{pH}$ at 6 for $\mathrm{Pb}^{2+}$ and 7 for $\mathrm{Cd}^{2+}$. The mixture was filtered and the metal ions in the filtrate was measured by atomic absorption spectrophotometer

\subsubsection{Effect of initial concentration of heavy metals}

$2.0 \mathrm{~g}$ of activated muscovite was stirred with $50 \mathrm{~mL}$ of a metal standard solution $\left(\mathrm{Cd}^{2+}\right.$ and $\left.\mathrm{Pb}^{2+}\right)$ for $2 \mathrm{hr}$ at $\mathrm{pH} 6$ for $\mathrm{Pb}^{2+}$ and $\mathrm{pH} 7$ for $\mathrm{Cd}^{2+}$, at different metal concentration $(10,20,30,50,75$ and $100 \mathrm{ppm}$ ) as initial concentration. The temperature was constant at $25^{\circ} \mathrm{C}$. The mixture filtered and the metal ions in the filtrate were measured by atomic absorption spectrophotometer.

\subsubsection{Effect of contact time}

$2.0 \mathrm{~g}$ of activated muscovite was stirred with $50 \mathrm{ml}$ of $50 \mathrm{ppm}$ of both $\mathrm{Cd}^{2+}$ and $\mathrm{Pb}^{2+}$ at $\mathrm{pH} 7$ for $\mathrm{Cd}^{2+}$ and $\mathrm{pH} 6$ for $\mathrm{Pb}^{2+}$. The effect of contact time was investigated for 30, 60, 120 and $180 \mathrm{~min}$ 
with solution temperature at $25^{\circ} \mathrm{C}$. The mixture was filtered and the metal ions were measured by atomic absorption spectrophotometer.

\subsubsection{Effect of temperature}

On stabilizing all above mentioned parameters. The effect of adsorption temperature was investigated at temperatures $25,35,45$ and $55^{\circ} \mathrm{C}$. The solution was filtered and the metal ion concentration $\left(\mathrm{Cd}^{2+}\right.$ and $\left.\mathrm{Pb}^{2+}\right)$ in the filtrate was measured by atomic absorption spectrophotometer.

\section{RESULTS AND DISCUSSION}

\subsection{Characterization of Muscovite before and after purification}

\subsubsection{SEM examination}

SEM micrographs of raw and purified muscovite (Figs.1-2) showed appearance of separated particles that particles are plate-like and the aggregated plates are compact from the edges with the face dimension of most particles being less than500 $\mu \mathrm{m}$. The muscovite layers are closely stacked together due to strong intermolecular forces (Fig. 1). After purification, the muscovite samples had a black grey appearance with increase in the surface undulation and in the interlayer thickness with no change in the particle basal dimensions. The internal layer space became less than $63 \mu \mathrm{m}$ (Fig. 2).

\subsubsection{XRD analysis}

For determination the structural change of muscovite before(BP) and after(AP) purification using XRD diffraction patterns was shown in Fig (3), the XRD of muscovite adsorbent before purification confirmed the presence of Muscovite (80)\%, Glauconite(12\%) Jahnsite(5\%), and Zinnwaldite(3\%)( Sander et al.2020) .After purification, it exhibited Muscovite(90\%), Coesite(3\%) and Richterite(7\%).From Fig (3), high intensity of Muscovite peaks at $2 \theta=$ $\left(9.7,27.1\right.$ and $\left.35.98^{\circ}\right)$ while lower intensity of peak at $2 \theta=\left(18,37.2\right.$ and $\left.45.43^{\circ}\right)$. Ismail et al,2017 found that the $\mathrm{d}(002)(9.9 \AA)$ of the main peak indicates that the original sample is muscovite.

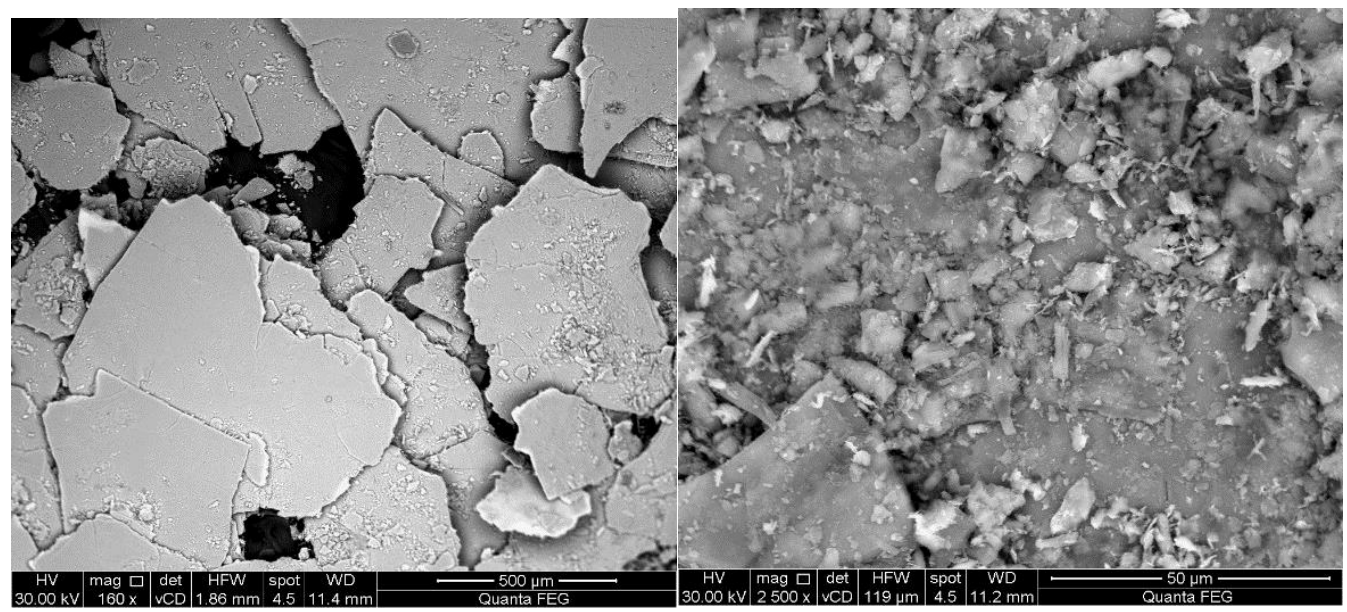

Fig. 1. SEM of raw Muscovite 


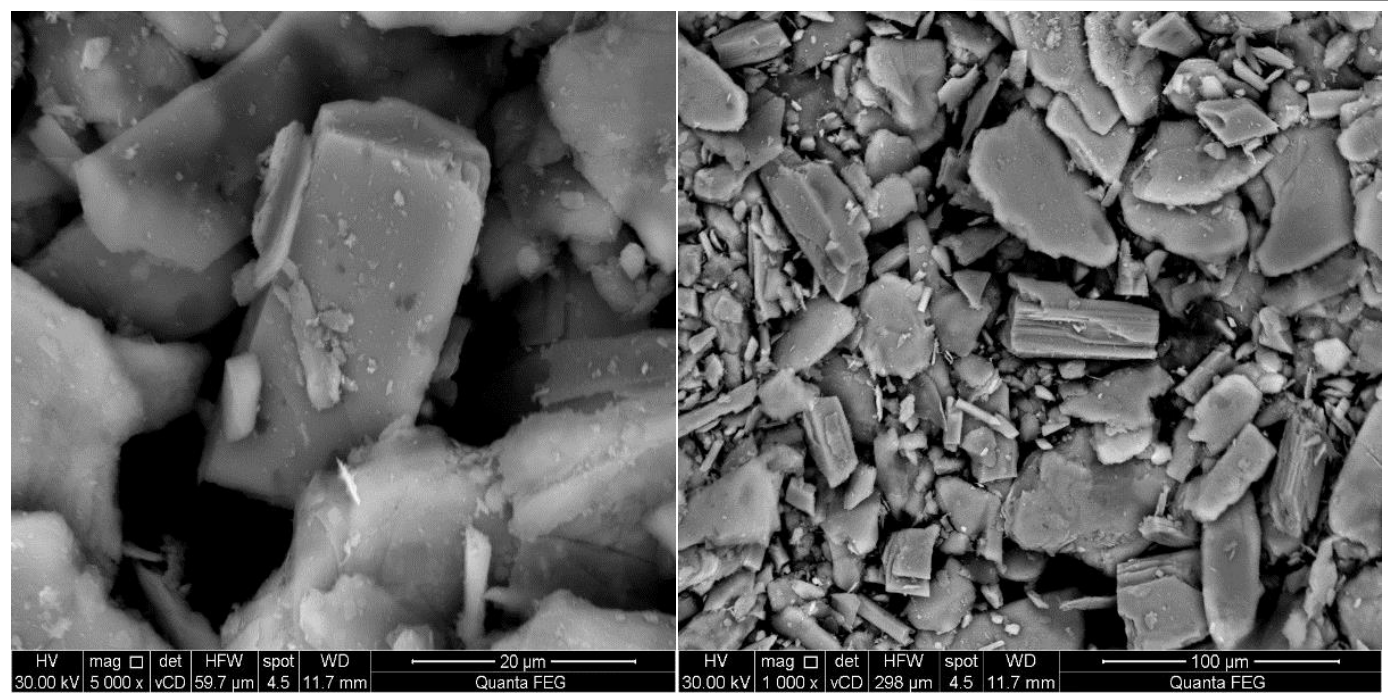

Fig. 2. SEM of purified muscovite

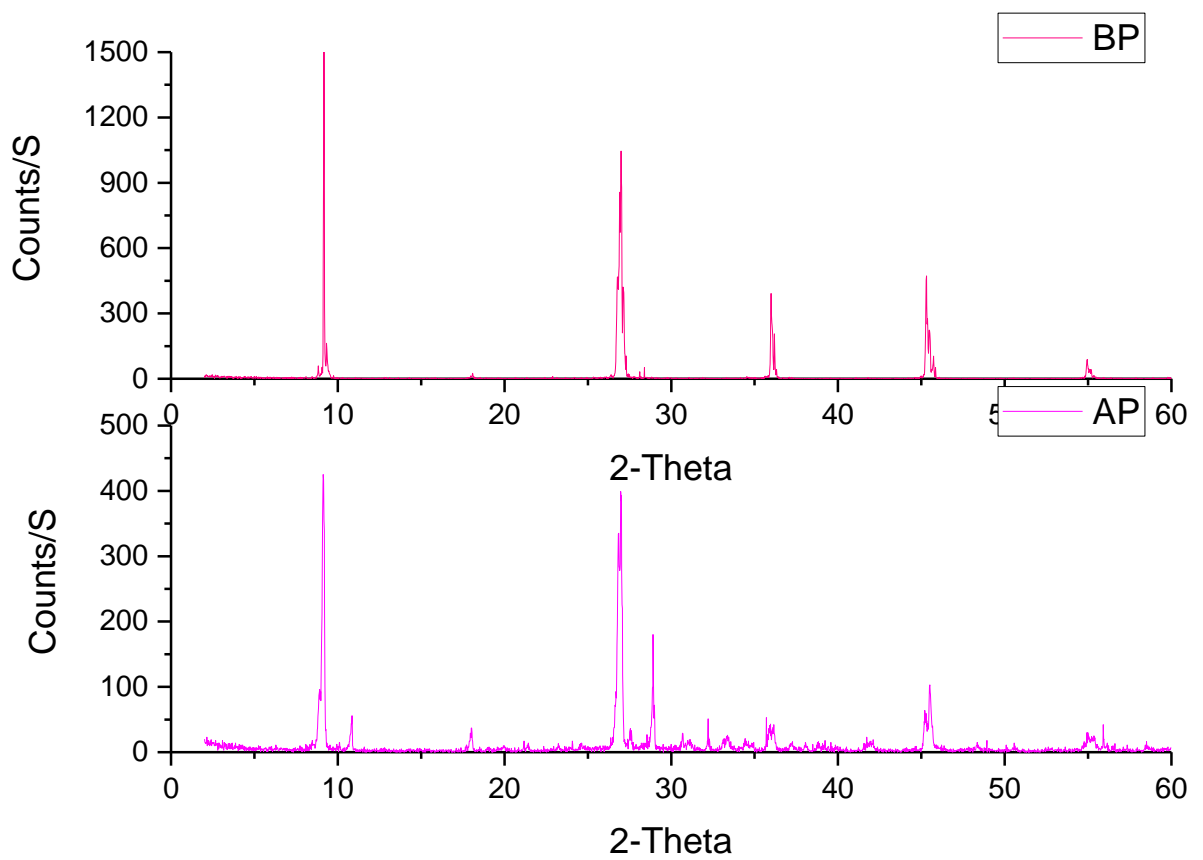

Fig. 3. XRD of raw and purified muscovite

\subsubsection{FTIR analysis}

FTIR spectroscopy is an effective analytical instrument for detecting functional groups and characterizing the covalent bonding information. As shown in Fig. (4), the FTIR spectra reveal the structural differences between raw and purified muscovite.

The absorption band at $3624 \mathrm{~cm}$ is due to the $\mathrm{OH}$ stretching vibration. Based on the transmittance bands, the structure of raw muscovite is similar with purified muscovite. The peak at $1113 \mathrm{~cm}^{-1}$ is assigned to Si-O stretching (longitudinal mode), while $1024-1019 \mathrm{~cm}^{-1}$ is the in-plane Si-O stretching 


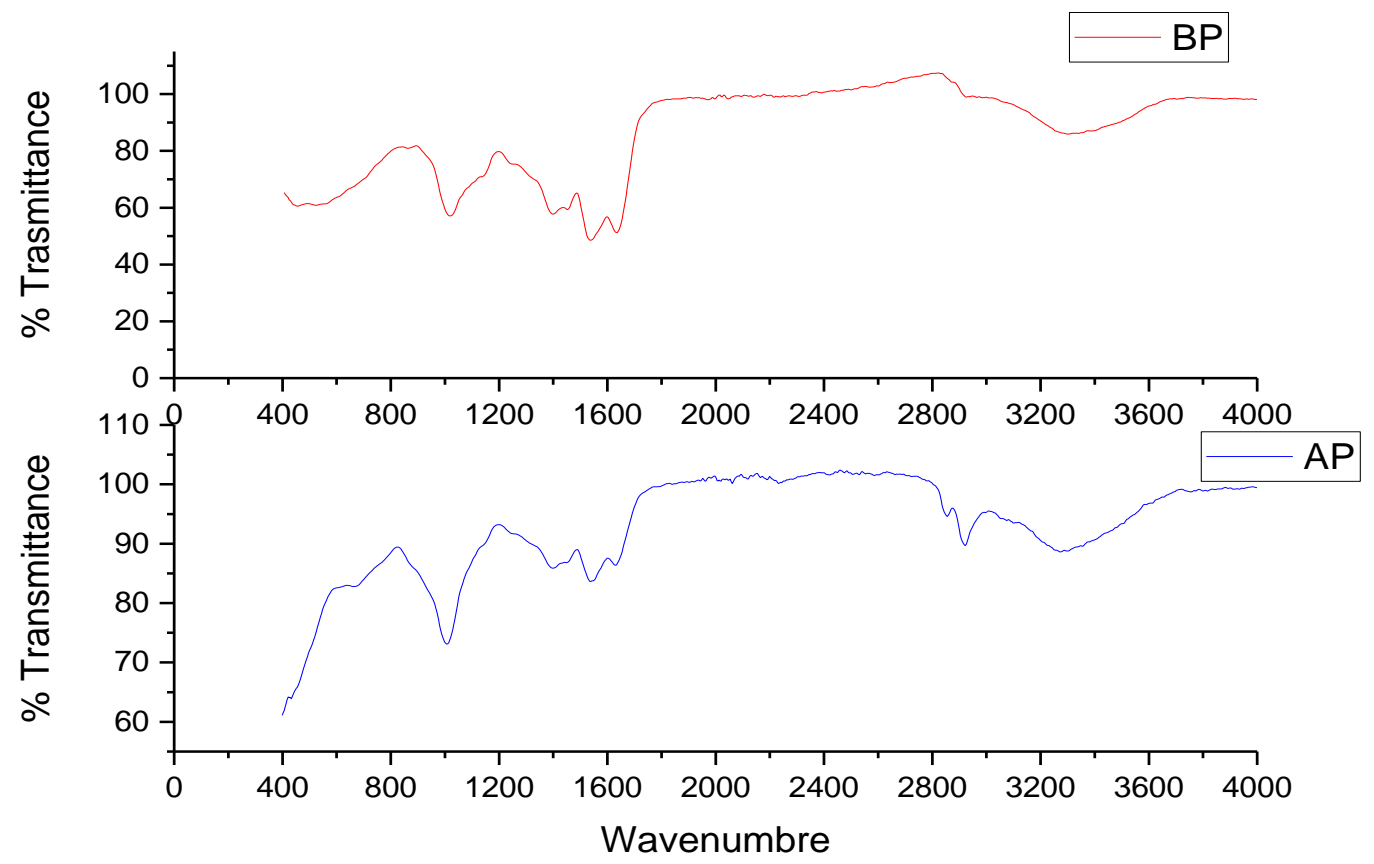

Fig.4 FTIR of raw and purified muscovite

\subsubsection{Surface area, BET and BJH analysis}

The surface area of samples was estimated by the BET method (Table 2). It was found that the surface area values for raw Muscovite was $55.97 \mathrm{~m}^{2} / \mathrm{g}$, while that for purified Muscovite it was $80.526 \mathrm{~m}^{2} / \mathrm{g}$. These results indicate the increase of the surface area of the purified Muscovite than that of the corresponding raw.

The pore size distribution was obtained by application of the BJH (Barrett-Joyner-Halenda) method for the desorption isotherm of the samples. Table (2) shows that the pore size of raw Muscovite was $16.14 \mathrm{~nm}$, and that for purified was $15.537 \mathrm{~nm}$.

The pore size of purified was smaller than the pore size of raw due to decreasing the particles of Muscovite via grinding.

Table 2. The pore size and surface area of raw and purified Muscovite

\begin{tabular}{|c|c|c|c|}
\hline Sample & $\begin{array}{c}\text { Surface area } \\
\left(\mathrm{m}^{2} / \mathrm{g}\right)\end{array}$ & Pore size $(\mathrm{nm})$ & $\begin{array}{c}\text { Pore volume } \\
\left(\mathrm{cm}^{3} / \mathrm{g}\right)\end{array}$ \\
\hline Raw Muscovite & 55.97 & 16.14 & 0.04184 \\
\hline Purified Muscovite & 80.5266 & 15.537 & 0.097 \\
\hline
\end{tabular}

\subsection{Characterization of Activated Muscovite}

\subsubsection{XRD analysis}

For determination the structural changes of the developed Muscovite before (PM) and after(AP) activation using XRD diffraction patterns of adsorbent was shown in Fig ( 5 ), the XRD of muscovite adsorbent before activation confirmed the presence of Muscovite, Coesite and Richterite. After activation it exhibited Illite, Biotite, Ankerite and Hematite, Quartz and 
Fluorophlogopite. Illite detected after activation, because muscovite may be transformed to illite by chemical processes. From Figure (5), high intensity of peaks at $2 \theta=\left(8.94 \& 26.56^{\circ}\right)$ while lower intensity of peak at $2 \theta=\left(17.8,35.9\right.$ and $\left.45.32^{\circ}\right)$ for illite was observed. Biotite has low intensity peak at $2 \theta=\left(34.2,37.1\right.$, and $\left.55.1^{\circ}\right)$. Moreover, it was noticed that peaks at $2 \theta=(30.9$, $33.1,37.1$ and $\left.55.1^{\circ}\right)$ refer to the presence of Ankerite, $2 \theta=\left(33.1,35.9,37.1\right.$ and $\left.55.1^{\circ}\right)$ for Hematite, $2 \theta=\left(17.1,20.8\right.$ and $\left.55.1^{\circ}\right)$ for Quartz and Fluorophlogopite shows low intensity peak at $2 \theta=\left(17.8,24.5,30.9,33.1,34.2\right.$ and $\left.41.8^{\circ}\right)$.

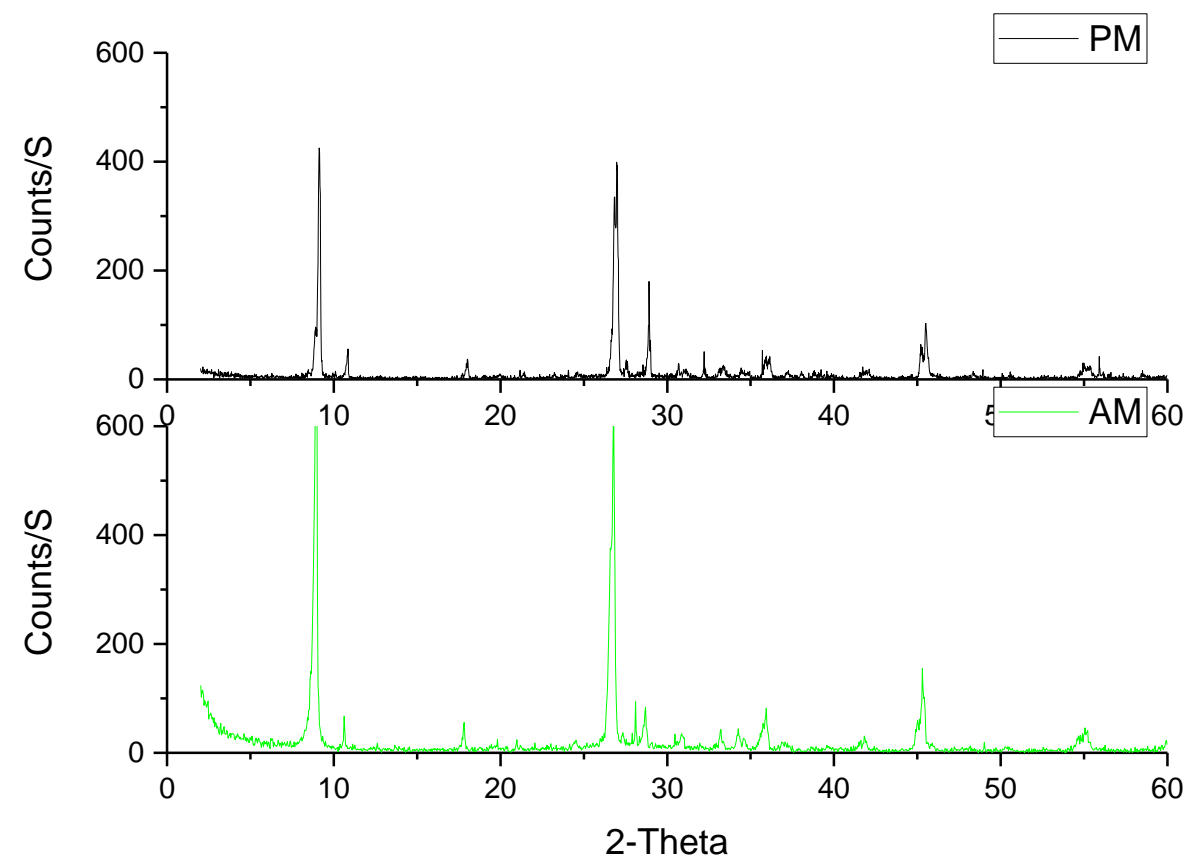

Fig. 5. XRD of purified and activated muscovite

\subsubsection{FTIR analysis}

As shown in Fig. (6), the FTIR spectra reveal the structural differences between purified and activated muscovite. The absorption band at $3624 \mathrm{~cm}$ was no longer exist due to illite formation. The peak at $1113 \mathrm{~cm}^{-1}$ is assigned to Si-O stretching (longitudinal mode), while $1024-1019 \mathrm{~cm}^{-1}$ is the in-plane $\mathrm{Si}-\mathrm{O}$ stretching.

\subsubsection{Surface area, BET and BJH analysis}

The surface area of samples was estimated by the BET method (Table 3). It was found that the surface area values for purified Muscovite was $80.5266 \mathrm{~m}^{2} / \mathrm{g}$, while that for activated Muscovite it was $137.659 \mathrm{~m}^{2} / \mathrm{g}$. These results indicate the increase of the surface area of the activated Muscovite than that of the corresponding purified.

Table 3. The pore size and surface area of purified and activated Muscovite

\begin{tabular}{|c|c|c|c|}
\hline Sample & Surface area $\left(\mathrm{m}^{2} / \mathrm{g}\right)$ & Pore size $(\mathrm{nm})$ & Pore volume $\left(\mathrm{cm}^{3} / \mathrm{g}\right)$ \\
\hline Purified Muscovite & 80.5266 & 15.537 & 0.097 \\
\hline Activated Muscovite & 137.659 & 14.501 & 0.145 \\
\hline
\end{tabular}




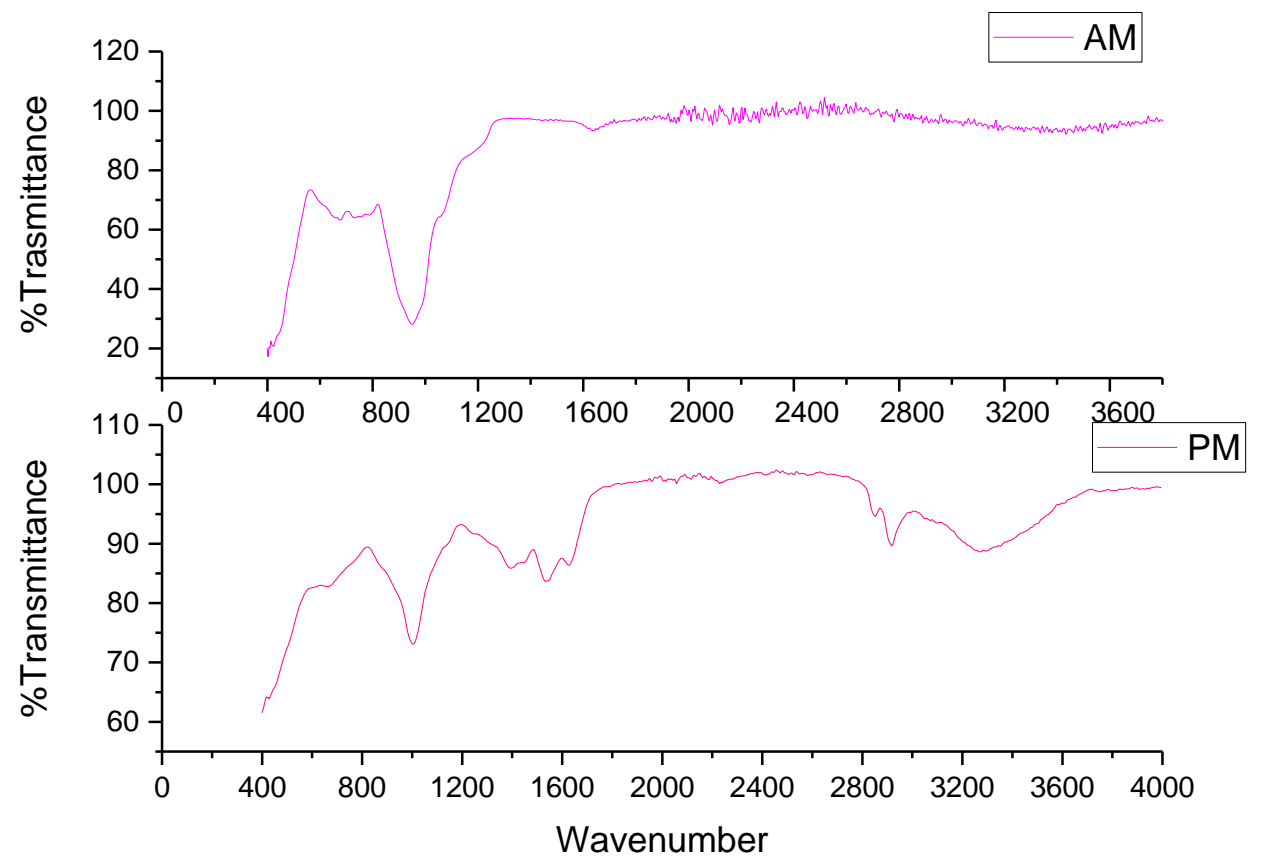

Fig. 6. FTIR of purified and activated muscovite

\subsection{A comparative study of the developed activated Muscovite for lead and cadmium removal efficiency}

The chemical activation of muscovite (Table4,5 and 6 ) showed that for the activation of muscovite with hydrochloric acid, the removal percent of $\mathrm{Pb}$ was the best at $0.8 \mathrm{M}$ hydrochloric acid (87\%) at stirring time $10 \mathrm{~h}(\mathrm{AM} 5)$ and $(85.4 \%)$ for $\mathrm{H}_{2} \mathrm{O}_{2}(30 \%)$ (AM14) at stirring time $8 \mathrm{~h}$ and also the removal percent of $\mathrm{Cd}$ was the best at $0.8 \mathrm{M}$ hydrochloric acid (67\%) at stirring time $10 \mathrm{~h}$ and $(67.6 \%)$ for $\mathrm{H}_{2} \mathrm{O}_{2}(30 \%)$ at stirring time $8 \mathrm{~h}$. So, the developed adsorbents AM5 and AM14 were selected as the most chemically activated Muscovite adsorbents

Table (4). Removal percent of lead and cadmium by chemically activated Muscovite adsorbent with $\mathrm{HCl}$.

\begin{tabular}{|c|c|c|c|c|c|c|}
\hline & \multicolumn{3}{|c|}{$\mathrm{Pb}$} & \multicolumn{3}{c|}{$\mathrm{Cd}$} \\
\hline Stirring time & $8 \mathrm{~h}$ & $10 \mathrm{~h}$ & $12 \mathrm{~h}$ & $8 \mathrm{~h}$ & $10 \mathrm{~h}$ & $12 \mathrm{~h}$ \\
\hline HCl Conc. (M) & \% removal & \% removal & $\%$ removal & \% removal & $\%$ removal & $\%$ removal \\
\hline 0.5 & 67.7 & 71.7 & 73 & 55.9 & 63.3 & 61.2 \\
0.8 & 84.4 & 87 & 76.8 & 65.8 & 67 & 62.9 \\
1.5 & 72.5 & 78.5 & 75.8 & 63.8 & 64.2 & 62 \\
2 & 75 & 75.4 & 71 & 62.7 & 64 & 61.7 \\
\hline
\end{tabular}


Table (5). Removal percent of lead and cadmium by chemically activated Muscovite adsorbents with $\mathrm{H}_{2} \mathrm{O}_{2}(30 \%)$

\begin{tabular}{|c|c|c|}
\hline \multirow{2}{*}{ Stirring time (h) } & \multicolumn{1}{|l|}{$\mathrm{Pb}$} & $\mathrm{Cd}$ \\
\cline { 2 - 3 } & Removal \% & Removal\% \\
\hline 6h & 74.9 & 57.8 \\
$7 \mathrm{~h}$ & 85.4 & 67.9 \\
$8 \mathrm{~h}$ & 78.7 & 60.6 \\
& & \\
\hline
\end{tabular}

Table 6. Removal percent of cadmium and lead by chemically activated Muscovite adsorbents with $\mathrm{H}_{2} \mathrm{O}_{2}(30 \%)$ and $\mathrm{HCl}$

\begin{tabular}{|l|c|c|}
\hline \multicolumn{1}{|c|}{ Stirring time (h) } & $\begin{array}{c}\text { Removal \% } \\
\mathrm{Pb}\end{array}$ & $\begin{array}{c}\text { Removal \% } \\
\mathrm{Cd}\end{array}$ \\
\hline $\mathrm{H}_{2} \mathrm{O}_{2}+\mathrm{HCl}$ (AM16) & 85.9016 & 81.7792 \\
$\mathrm{H}_{2} \mathrm{O}_{2}+\mathrm{HCl}$ (AM17) & 94.9576 & 83.6572 \\
\hline
\end{tabular}

\subsection{Optimum parameters for the adsorption of heavy metals on activated Muscovite}

\subsubsection{Effect of pH on heavy metals adsorption}

The $\mathrm{pH}$ of $\mathrm{Cd}^{2+}$ and $\mathrm{Pb}^{2+}$ solution plays an important role in the whole adsorption process. The effect of solution $\mathrm{pH}$ on the adsorption of $\mathrm{Cd}^{2+}$ and $\mathrm{Pb}^{2+}$ on activated Muscovite were determined at $\mathrm{pH} \mathrm{2,4} \mathrm{5,6} \mathrm{7,8} \mathrm{and} 10$ with fixed adsorbent dose of $0.2 \mathrm{~g} / 50 \mathrm{ml}$, heavy metals concentrations $50 \mathrm{ppm}$, temperature $25^{\circ} \mathrm{C}$ and contact time $120 \mathrm{~min}$. The $\mathrm{pH}$ of the solution was controlled by addition of $0.1 \mathrm{M} \mathrm{HNO}_{3}$ or $0.1 \mathrm{NaOH}$. The results showed in Figure (7) pointed that the removal percentage of $\mathrm{Cd}^{2+}$ and $\mathrm{Pb}^{2+}$ increased with increased $\mathrm{pH}$ from 2 to 7 for $\mathrm{Cd}^{2+}$ and from 2 to 6 for $\mathrm{Pb}^{2+}$. Adsorption removal percentage increased for $\mathrm{Cd}^{2+}$ from 20.4 to $64.6 \%$, for $\mathrm{Pb}^{2+}$ from 39.2 to $72.8 \%$.

At low $\mathrm{pH}$ (less than 4.0) heavy metal removal was inhibited, possibly as a result of a positive charge density on metal binding sites due to a high concentration of protons in solution. With an increase in the $\mathrm{pH}$, the negative charge density on the activated carbon surface increases due to deprotonation of the metal binding sites and thus increases adsorption. Experiments were carried out with the $\mathrm{pH}$ values of 7 due to the fact that metal precipitation appeared at higher $\mathrm{pH}$ values (Puranik et al, 1997; Gadd,1988)

\subsubsection{Effect of adsorbent dosage}

In these experiments, $\mathrm{Cd}^{2+}$ and $\mathrm{Pb}^{2+}$ solutions with a concentration of $50 \mathrm{ppm}$ were placed in contact with various amount of activated Muscovite $(0.1,0.2,0.3,0.5,1.0,2.0$ and $3.0 \mathrm{~g})$, keeping other parameter $(\mathrm{pH}$, contact time and temperature) constant.

The results are presented in Figure (8) show that the removal percentage of $\mathrm{Cd}^{2+}$ and $\mathrm{Pb}^{2+}$ increases with increase activated muscovite adsorbent dose. The removal percentage of $\mathrm{Cd}^{2+}$ increase from $42.8 \%$ to $96.7 \%$ and from $58.4 \%$ to $97.6 \%$ with increase in adsorbent dose to $2 \mathrm{~g}$. This increase of heavy metals removal resulted from the increase of the number available adsorption site in adsorbents till certain number after that accumulation on adsorbent occurred, so 
removal percentage decrease. With increasing adsorbent dosage more surface area is available for the adsorption due to increase in active sites on the adsorbent and that increasing this number had also no effect after equilibrium was reached (Gerçel and Gerçel,2007).

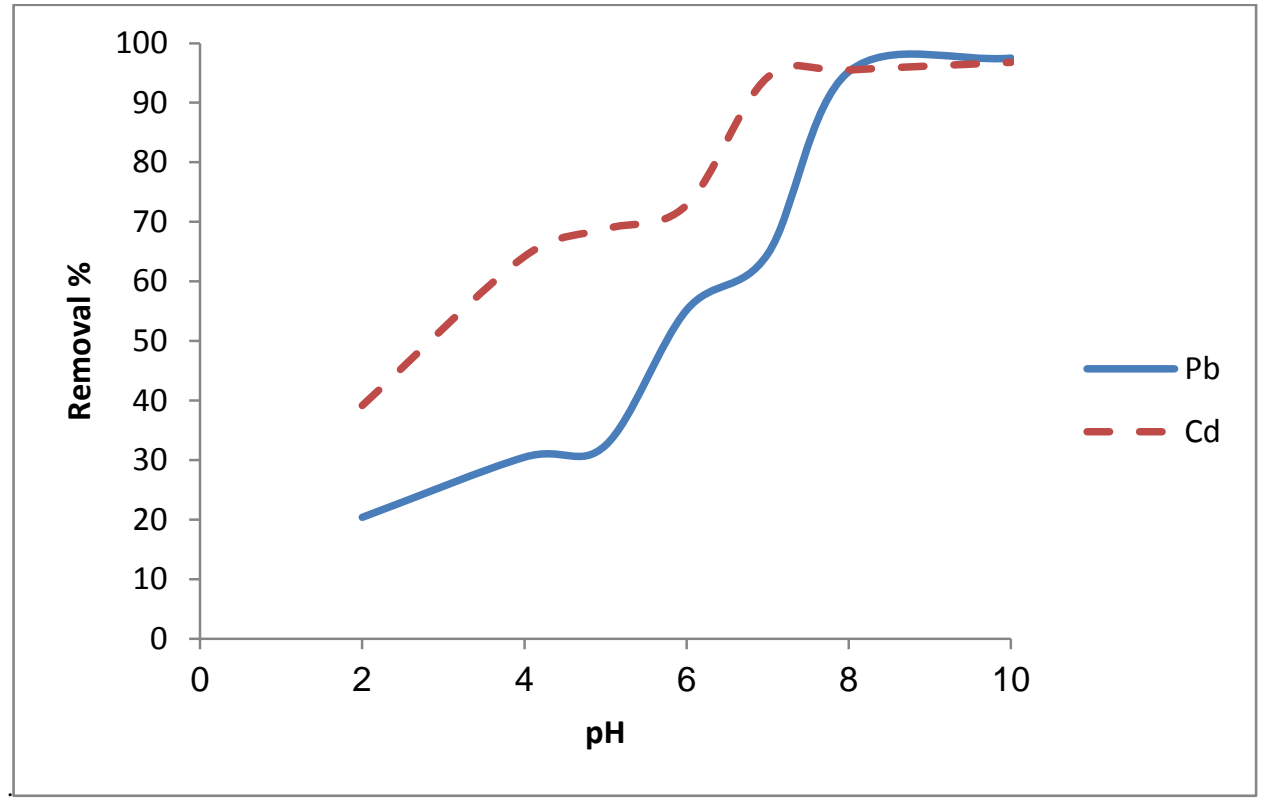

Fig7. Adsorption of $\mathrm{Cd}^{2+}$ and $\mathrm{Pb}^{2}$ on activated muscovite according to $\mathrm{pH}$

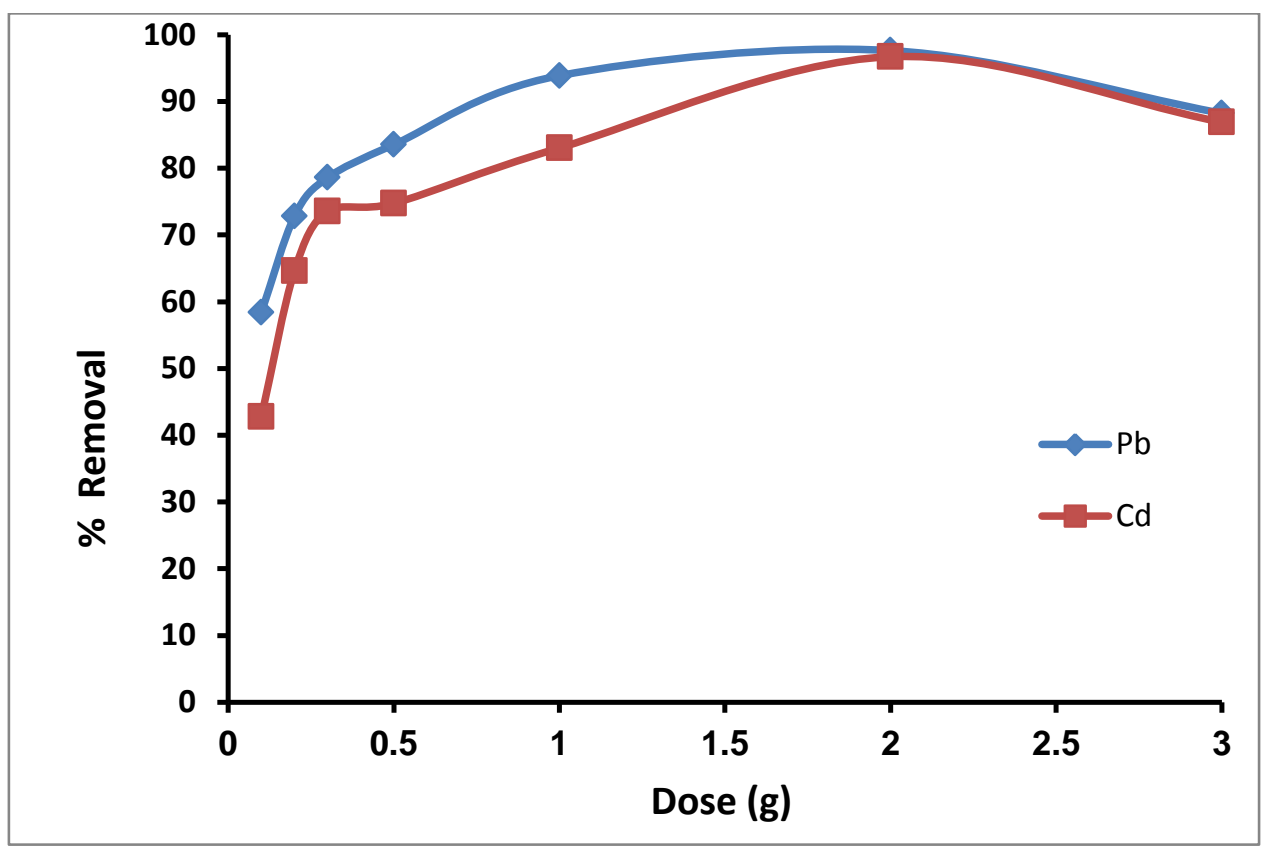

Fig. 8. Adsorption of $\mathrm{Cd}^{2+}$ and $\mathrm{Pb}^{2+}$ on activated muscovite according to adsorbent dose

\subsubsection{Effect of initial heavy metals concentration on the adsorption}

The optimum $\mathrm{Cd}^{2+}$ and $\mathrm{Pb}^{2+}$ initial concentration for the maximum adsorption on activated Muscovite adsorbent was studied by varying the $\mathrm{Cd}^{2+}$ and $\mathrm{Pb}^{2+}$ concentration from 10-100 ppm, at constant temperature $25^{\circ} \mathrm{C}$, adsorbent dose $2.0 \mathrm{~g}, \mathrm{pH} 7$ for $\mathrm{Cd}^{2+}$ and $\mathrm{pH} 6$ for $\mathrm{Pb}^{2+}$ contact time at $120 \mathrm{~min}$. The effect of initial concentration on the removal of $\mathrm{Cd}^{2+}$ and $\mathrm{Pb}^{2+}$ by the adsorbent 
was represented in Figure (9). The data evident that removal percentage increases from $68.52 \%$, $70.7 \%$ to $96.7 \%, 97.6 \%$, then decreases to $72.8 \%, 85.23 \%$ for $\mathrm{Cd}^{2+}$ and $\mathrm{Pb}^{2+}$ respectively with increase concentration. This is due to that with increase concentration, surface area and active sites of the adsorbent saturated and hence percentage removal decreases. This result refers to that the best concentration of $\mathrm{Cd}^{2+}$ and $\mathrm{Pb}^{2+}$ was $50 \mathrm{ppm}$ for the adsorption on activated Muscovite adsorbent. At low metal concentrations, the ratio between the active sites and metal ions was high which favor the adsorption of the heavy metal ions and hence the removal efficiency increased. Concentration increasing of metal ions would lead to decreasing in the diffusion velocity of the heavy metal ions (Erdem et al., 2004). Besides, it allows each active site to be subjected to a larger number of metal cations that decreases the driving force for the removal process which, by its role, decreases the overall removal efficiency. Similar result was found by Wu et al. (2008) who reported that the increase of initial zinc concentration leads to a reduction of the removal efficiency.

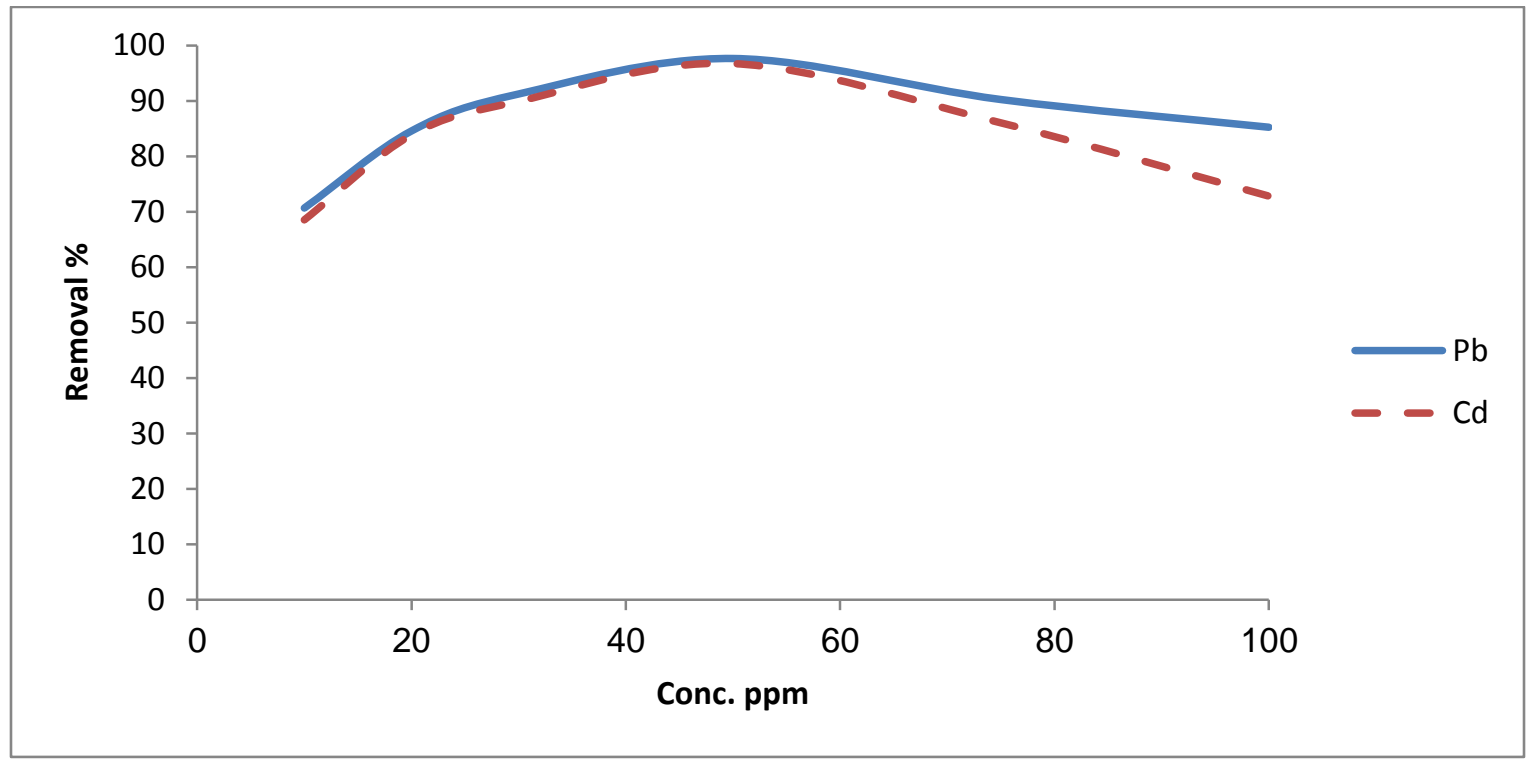

Fig 9. Removal of $\mathrm{Cd}^{2+}$ and $\mathrm{Pb}^{2+}$ by activated muscovite according to initial metal concentration

\subsubsection{Effect of contact time on heavy metals adsorption}

In order to determine the optimum contact time to maximum $\mathrm{Cd}^{2+}$ and $\mathrm{Pb}^{2+}$ adsorption, its value was varied at times 30,60,120, and $240 \mathrm{~min}$ in series of experiment, keeping other parameters constant. The effect of contact time on removal of heavy metals was indicated in Figure (10). The result refers to that the best contact time of $\mathrm{Cd}^{2+}$ and $\mathrm{Pb}^{2+}$ was $60 \mathrm{~min}$ for the adsorption on activated Muscovite adsorbent.

\subsection{Effect of temperature on heavy metals adsorption}

The effect of temperature on the adsorption of $\mathrm{Cd}^{2+}$ and $\mathrm{Pb}^{2+}$ had been studied with different temperatures $\left(25^{\circ} \mathrm{C}, 35^{\circ} \mathrm{C}, 45^{\circ} \mathrm{C}\right.$ and $\left.60^{\circ} \mathrm{C}\right)$. The results were represented in Figure (11). The results showed that the removal percentage of $\mathrm{Cd}^{2+}$ and $\mathrm{Pb}^{2+}$ on activated muscovite increased at room temperature. 


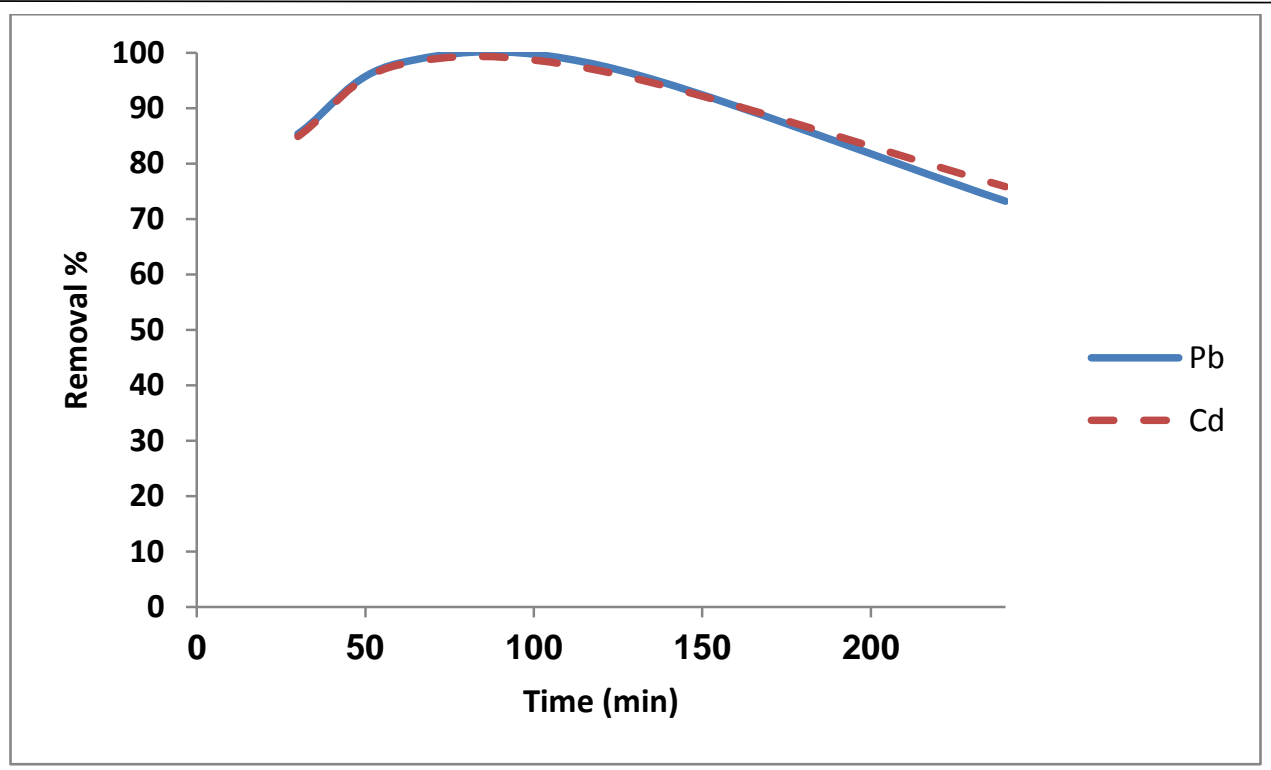

Fig.10. Removal of $\mathrm{Cd}^{2+}$ and $\mathrm{Pb}^{2+}$ on activated muscovite according to contact time

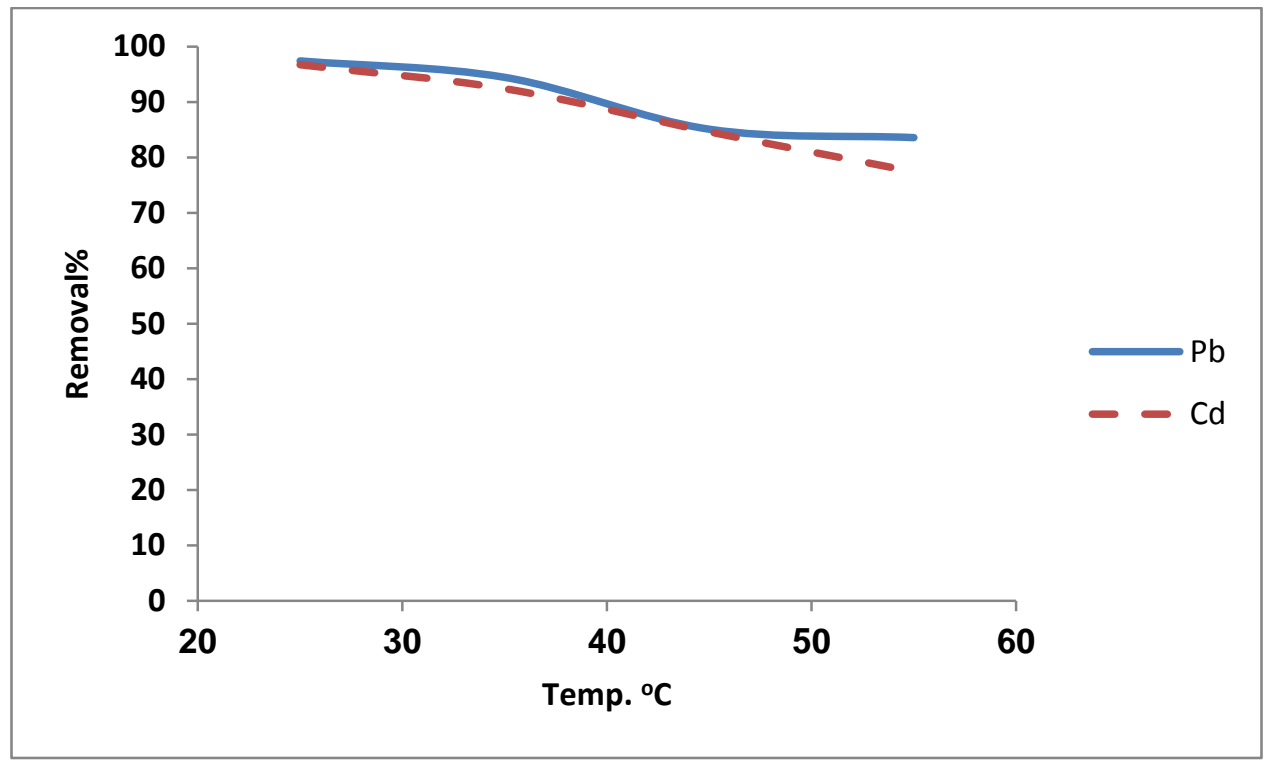

Fig. 11. Removal of $\mathrm{Cd}^{2+}$ and $\mathrm{Pb}^{2+}$ by activated muscovite according to temperature

\subsubsection{Adsorption Isotherm}

The experimental data collected at $25^{\circ} \mathrm{C}$ and initial heavy metals concentration of $50 \mathrm{ppm} / 50 \mathrm{~mL}$ with $2 \mathrm{~g}$ of activated muscovite at $60 \mathrm{~min}$ contact time. The data was fitted into the following isotherms: Langmuir, Freundlich, Temkine and Dubinin-Raduskevich (D-R) isotherm models.

\subsubsection{Langmuir isotherm}

The Langmuir model assumes that the solid surface carries a limited number of sites that are characterized by equal energy of adsorption, independent of the degree of coverage and thus indicating a monolayer adsorption. The linearized form of Langmuir equation is described by equation: 


$$
\mathrm{C}_{\mathrm{e}} / \mathrm{q}_{\mathrm{e}}=1 / \mathrm{Qob}+\mathrm{C}_{\mathrm{e}} / \mathrm{Q}_{\mathrm{o}}
$$

Where $\mathrm{C}_{\mathrm{e}}$, is the equilibrium concentration of heavy metals solution $(\mathrm{mg} / \mathrm{L}), \mathrm{q}_{\mathrm{e}}$ the equilibrium capacity of heavy metals on adsorbent $(\mathrm{mg} / \mathrm{g}), \mathrm{Q}_{\mathrm{o}}$ is monolayer adsorption capacity of adsorbent $(\mathrm{mg} / \mathrm{g})$ and $\mathrm{b}$, is the Langmuir bonding energy coefficient $(\mathrm{L} / \mathrm{mg})$.

The $b$ and $Q_{o}$ can be calculated from the intercept and slope of the linear plot of $C_{e} / q_{e}$ against $C_{e}$.

\subsubsection{Freundlich isotherm}

The Freundlich equation is used to determining the applicability of heterogeneous surface energy in the adsorption process. The empirical Freundlich equation is expressed as:

$$
\log \mathrm{q}_{\mathrm{e}}=\log \mathrm{K}_{\mathrm{f}}+1 / \mathrm{n} \log \mathrm{C}_{\mathrm{e}}
$$

Where $\mathrm{K}_{\mathrm{f}}$, is the Freundlich isotherm constant indicating the adsorption capacity and $\mathrm{n}$, is the adsorption intensity. If the $1 / \mathrm{n}$ values are below one it indicates a normal adsorption on the other hand $1 / \mathrm{n}$ being above one indicates cooperation adsorption. The $\mathrm{K}_{\mathrm{f}}$ and $\mathrm{n}$ can be calculated from the intercept and slope of the linear plot of $\log \mathrm{q}_{\mathrm{e}}$ against $\log \mathrm{C}_{\mathrm{e}}$.

\subsubsection{The Temkin isotherm}

Temkin isotherm model predicts a uniform distribution of binding energies over the population of surface binding adsorption. Linear form of Temkin equation is expressed as:

$$
\mathrm{q}_{\mathrm{e}}=\mathrm{B} \ln \mathrm{K}+\mathrm{B} \ln \mathrm{C}_{\mathrm{e}}
$$

Where $B=R T / b, b$ is the Temkin constant related to heat of sorption. $q_{e}(m g / g)$ and $C_{e}(m g / L)$ are the amount of adsorbed heavy metals per unite weight of adsorbent and unabsorbed heavy metals concentration in solution at equilibrium, respectively. Therefore, a plot of $\mathrm{q}_{\mathrm{e}}$ versus $\ln \mathrm{C}_{\mathrm{e}}$ to determine the constant B which is the constant related to the heat of sorption $(\mathrm{J} / \mathrm{mol})$ and $\mathrm{K}$, is the Temkin isotherm equilibrium binding constant.

\subsubsection{Dubinin-Radushkevich isotherm model}

Dubinin-Radushkevich isotherm is generally applied to express the adsorption mechanism with a Gaussian energy distribution onto a heterogeneous surface (Gunay et al., 2007; Dabrowski, 2001). It means that,it is applied to distinguish between physical and chemical adsorption of heavy metals.

The linearized D-R equation (Chen et al., 2008) can be written as:

$$
\operatorname{Ln} \mathrm{q}_{\mathrm{e}}=\ln \mathrm{q}_{\mathrm{m}}-\mathrm{BE}^{2}
$$

Where $\mathrm{B}$, is a constant related to the adsorption energy $(\mathrm{mol} / \mathrm{kJ}), \mathrm{q}_{\mathrm{m}}$ is a constant that indicates the sorption degree characterizing the sorbent $(\mathrm{mg} / \mathrm{g})$, and $\mathrm{E}$, is the polanyi potential, which can be obtained by following equation:

$$
\mathrm{E}=\mathrm{RT} \ln \left(1+1 / \mathrm{C}_{\mathrm{e}}\right)
$$

Where $\mathrm{R}$, is the ideal gas constant $(\mathrm{R}=8.314 \mathrm{~J} / \mathrm{mol} \mathrm{K})$ and $\mathrm{T}$ is absolute temperature $(\mathrm{K})$.

By plotting ln qe vs $E^{2}$, it is possible to determine the value of $B$ from the slope and the value of qm from the intercept, which is $\ln \mathrm{qm}$. The mean free energy $\mathrm{E}(\mathrm{KJ} / \mathrm{mol})$ of sorption can be estimated by using B values as expressed in the following equation (Chowdhury and Saha, 2010).

$$
\mathrm{E}=1 /(2 \mathrm{~B}) \mathrm{1} / 2
$$


The magnitude of $\mathrm{E}$ may characterize the type of the adsorption as chemical ion exchange $(\mathrm{E}=8$ $16 \mathrm{~kJ} / \mathrm{mol}$ ), or physical adsorption (E $<8 \mathrm{~kJ} / \mathrm{mol})$, (Sivakumar and Rupainwar, 2011)

All of the isotherm model parameters for the adsorption of $\mathrm{Pb}$ and $\mathrm{Cd}$ are provided in Table 7. As seen from Table 7 in Langmuir isotherm calculated adsorption capacities for cadmium and lead are 22.95 and $23.127 \mathrm{mg} / \mathrm{g}$, respectively.

In the Freundlich isotherm, calculated values of $1 / \mathrm{n}$ for cadmium and lead, are 0.1269and 0.2125, respectively, indicates an effective adsorption and also indicates degree of favorability of adsorption. Higher values of $\mathrm{K}$ (isotherm equilibrium binding) and lower values of $\mathrm{B}$ for cadmium and lead, This means that the adsorption of RB on alum and mud sludge adsorbents follows the Temkin model.

By using D-R isotherm, adsorption energies for cadmium and lead are calculated as 1.58 and $0.316(\mathrm{~kJ} / \mathrm{mol})$. These low values of adsorption energy show that the adsorption has a physical nature.

Table 7. Results of adsorption isotherm parameters for $\mathrm{Cd}^{2+}$ and $\mathrm{Pb}^{2+}$

\begin{tabular}{|c|c|c|}
\hline Parameters & $\mathrm{Pb}$ & $\mathrm{Cd}$ \\
\hline \multicolumn{3}{|c|}{ Langmuir Isotherm model } \\
\hline $\mathrm{Q}_{0}$ & 22.95 & 23.127 \\
\hline $\mathrm{b}_{\mathrm{L}}(\mathrm{L} / \mathrm{mg})$ & 0.63 & 0.15 \\
\hline $\mathrm{R}^{2}$ & 0.9835 & 0.9778 \\
\hline \multicolumn{3}{|c|}{ Freundlich Isotherm model } \\
\hline $1 / \mathrm{n}$ & 0.2125 & 0.1269 \\
\hline $\mathrm{K}_{\mathrm{f}}\left(\mathrm{mg}^{-1 / \mathrm{n}} \mathrm{L}^{1 / \mathrm{n}} \mathrm{g}^{-1}\right)$ & 17.18 & 16.22 \\
\hline $\mathrm{R}^{2}$ & 0.977 & 0.9 \\
\hline \multicolumn{3}{|c|}{ Temkin Isotherm model } \\
\hline$B(j / m o l)$ & 2.34 & 2.546 \\
\hline $\mathrm{b}_{\mathrm{T}}$ & 1058.8 & 973.2 \\
\hline $\mathrm{Kt}(\mathrm{L} / \mathrm{g})$ & 192.2 & 153.2 \\
\hline $\mathrm{R}^{2}$ & 0.95 & 0.9134 \\
\hline \multicolumn{3}{|c|}{ Dubin-Raduskevich Isotherm model } \\
\hline $\mathrm{q}_{\mathrm{m}}(\mathrm{mg} / \mathrm{g})$ & 17.1 & 15.74 \\
\hline $\mathrm{E}(\mathrm{kj} / \mathrm{mol})$ & 1.58 & 0.316 \\
\hline $\mathrm{R}^{2}$ & 0.8513 & 0.9478 \\
\hline $\mathrm{B}\left(\mathrm{mol} / \mathrm{kJ}^{2}\right)$ & $2 * 10^{-7}$ & $5^{*} 10^{-6}$ \\
\hline
\end{tabular}

\subsection{Kinetic Studies}

Kinetic models have been proposed to determine the mechanism of the adsorption process which provides useful data to improve the efficiency of the adsorption and feasibility of process scaleup (Eftekhari et al., 2010), It means to describe the rate of uptake of heavy metalss onto the 
adsorbents and this rate controls the equilibrium time. The kinetics of sorption that define the efficiency of sorption RB heavy metals on Alum and Mud sludge adsorbent were checked by the Pseudo-first order, Pseudo-second order, Intra-particle diffusion and Elovich models.

\subsubsection{Pseudo-first order model}

The pseudo- first order kinetic model is represented as follows:

$$
\log \left(\mathrm{q}_{\mathrm{e}}-\mathrm{q}_{\mathrm{t}}\right)=\log \mathrm{q}_{\mathrm{e}}-\left(\mathrm{K}_{1} / 2.303\right) \mathrm{t}
$$

Where, $\mathrm{q}_{\mathrm{e}}$ and $\mathrm{qt}(\mathrm{mg} / \mathrm{g})$, are the sorption capacities at equilibrium and time ( $\mathrm{min}$ ) respectively, and $\mathrm{K}_{1}$, is the rate constant of the pseudo- first order (Kamal et al., 2010; Inbaraj and Sulochana, 2006). A plot of $\log \left(\mathrm{q}_{\mathrm{e}}-\mathrm{q}_{\mathrm{t}}\right)$ vs $\mathrm{t}$ should give linear relationship with the slop $\mathrm{k}_{1}$ and intercept of $\log \mathrm{q}_{\mathrm{e}}$

\subsubsection{Pseudo-second order model}

The linearized form of the pseudo - second order kinetic model is represented as:

$$
\mathrm{t} / \mathrm{q}_{\mathrm{t}}=1 / \mathrm{K}_{2} \mathrm{q}_{\mathrm{e}}{ }^{2}+1 / \mathrm{q}_{\mathrm{e}} \mathrm{t}
$$

Where $\mathrm{K}_{2}$ is the rate constant of pseudo-second order adsorption

A plot of $t / q_{t}$ vs $t$ shows a linear relationship values of $\mathrm{K}_{2}$ and equilibrium adsorption capacity $\mathrm{q}_{\mathrm{e}}$ are calculated from intercept and slop of the plot. In order to calculate the adsorption rate constants of cadmium and lead, the first order reaction kinetic was applied for both metals Pseudo-second-order kinetic was also applied for the experimental data of each metal.

The values of qe calculated are found from the intersection points of the first and second degree reaction kinetic curves. Table (8) presents all of the data.

As the difference between $Q E$, calculated and $\mathrm{QE}$, experimental values are considered, it is seen that the $\mathrm{Cd}^{2+}$ and $\mathrm{Pb}^{2+}$ removal with activated Muscovite is well described by the second order reaction kinetics. Moreover, all the correlation coefficients $\left(\mathrm{R}^{2)}\right.$ of second order reaction kinetics are higher than that of the first order reaction kinetics.

\subsubsection{Intra-particle diffusion model}

For solid-liquid, adsorption process, the solute transfer is usually characterized by intra-particle diffusion model was used to identify the mechanism involved in adsorption process:

$$
\mathrm{q}_{\mathrm{t}}=\mathrm{K}_{\mathrm{i}} \mathrm{t} 1 / 2+\mathrm{C}
$$

Where, $\mathrm{K}_{\mathrm{i}}\left(\mathrm{mg} \mathrm{g}^{-1} \mathrm{~min}^{-1 / 2}\right)$, is the rate constant of the intra-particle diffusion model and $\mathrm{C}\left(\mathrm{mg} \mathrm{g}^{-1}\right)$ reflects the boundary layer effect. The $\mathrm{K}_{\mathrm{i}}$ and $\mathrm{C}$ can be determined from the slop and intercept of the linear plot of $\mathrm{q}_{\mathrm{t}} \mathrm{vs} \mathrm{t}^{1 / 2}$.

The experimental data were used for intraparticle diffusion model, the intraparticle diffusion constant (Kid), intercept and the correlation coefficient $\left(\mathrm{R}^{2}\right)$ are calculated.

\subsubsection{Elovich model}

One of the most useful models for describing such activated chemisorptions is Elovich equation.

$$
\text { The Elovich equation was: } \mathrm{q}_{\mathrm{t}}=1 / \beta \ln [\alpha \beta]+1 / \beta \ln \mathrm{t}
$$

Where, $\alpha$, the initial adsorption $\beta$, the adsorption coefficient 
The constant $\alpha$ and $\beta$ are calculated from plots obtained when $\mathrm{q}_{\mathrm{e}}$ is plotted vs $\ln \mathrm{t}$.

Table (8) Calculated kinetic parameters for the adsorption of $\mathrm{Cd}^{2+}$ and $\mathrm{Pb}^{2+}$

\begin{tabular}{|c|c|c|}
\hline Parameters & $\mathrm{Pb}$ & $\mathrm{Cd}$ \\
\hline \multicolumn{3}{|c|}{ Pseudo first-order } \\
\hline $\mathrm{K}_{1}(\min )^{-1}$ & 0.115 & 0.2 \\
\hline $\mathrm{q}_{\mathrm{e}}(\mathrm{mg} / \mathrm{g})$ & 18.76 & 20.5 \\
\hline $\mathrm{R}^{2}$ & 0.886 & 0.826 \\
\hline \multicolumn{3}{|c|}{ Pseudo second-order } \\
\hline $\mathrm{K}_{2}(\mathrm{~g} / \mathrm{mg} \min )$ & $5.9 * 10^{-3}$ & $4.6 * 10^{-4}$ \\
\hline $\mathrm{q}_{\mathrm{e}}(\mathrm{mg} / \mathrm{g})$ & 19.96 & 14.3 \\
\hline $\mathrm{R}^{2}$ & 0.996 & 0.999 \\
\hline \multicolumn{3}{|c|}{ Elovich model } \\
\hline$\alpha(\mathrm{mg} / \mathrm{min})$ & 9.2 & 5.13 \\
\hline$\beta(\mathrm{g} / \mathrm{mg})$ & 0.52 & 0.6 \\
\hline $\mathrm{R}^{2}$ & 0.95 & 0.95 \\
\hline \multicolumn{3}{|c|}{ Intra particle diffusion model } \\
\hline $\mathrm{K}_{\mathrm{id}}$ & 0.54 & 0.616 \\
\hline $\mathrm{C}\left(\mathrm{mg} \mathrm{g}^{-1}\right)$ & 5.33 & 7.28 \\
\hline $\mathrm{R}^{2}$ & 0.82 & 0.82 \\
\hline
\end{tabular}

\subsection{Thermodynamics of adsorption}

The thermodynamic parameters such as changes in Gibbs free energy $\left(\Delta \mathrm{G}^{0}\right)$, enthalpy $\left(\Delta \mathrm{H}^{\mathrm{o}}\right)$ and entropy $\left(\Delta S^{0}\right)$ are the actual indicators for particle applications.

Adsorption thermodynamics was evaluated with respect to different temperatures $(298,313$, and $333 \mathrm{~K})$.

The thermodynamic parameters were calculated by the following equation:

$$
\text { Ln } \mathrm{K}=\Delta \mathrm{S}^{\mathrm{o}} / \mathrm{R}-\Delta \mathrm{H}^{\mathrm{o}} / \mathrm{RT}
$$

Where, $\mathrm{R}$ is the gas constant $(8.314 \mathrm{~J} / \mathrm{mol} \mathrm{K})$ and $\mathrm{T}$ is temperature $(\mathrm{K})$

Both $\Delta \mathrm{H}^{\mathrm{o}}$ and $\Delta \mathrm{S}^{\mathrm{o}}$ were determined from the slope and intercept of the van't Hoff plots of ln $\mathrm{k}$ vs 1/T (Ozcan et al., 2006; Nollet et al., 2003).

The free energy of specific adsorption $\Delta \mathrm{G} 0(\mathrm{KJ} / \mathrm{mol})$ is calculated from the following expression.

$$
\Delta \mathrm{G}^{\mathrm{o}}=\Delta \mathrm{H}^{\mathrm{o}}-\mathrm{T} \Delta \mathrm{S}^{\mathrm{o}}
$$

The estimated thermodynamic parameters are presented in Table (9). The adsorption data indicate that $\Delta \mathrm{G}^{\circ}$ values for cadmium and lead were negative at all temperatures. That negative $\Delta \mathrm{G}^{\circ}$ confirms the spontaneous nature of adsorption of $\mathrm{Cd}^{2+}$ and $\mathrm{Pb}^{2+}$ by activated Muscovite. The parameter $\Delta \mathrm{G}^{\circ}$ suggests that adsorption of $\mathrm{Cd}^{2+}$ and $\mathrm{Pb}^{2}$ is physical adsorption process. The 
positive values of $\Delta \mathrm{H}^{\circ}$ confirmed the endothermic nature of adsorption process. The positive $\Delta \mathrm{S}^{\circ}$ showed increased randomness at the solid-solution interface during the adsorption.

Table (9) Thermo dynamical parameters for the adsorption of $\mathrm{Cd}^{2+}$ and $\mathrm{Pb}^{2+}$

\section{Conclusion}

\begin{tabular}{|c|c|c|c|}
\hline \multicolumn{2}{|c|}{ Parameters } & $\mathrm{Cd}$ & $\mathrm{Pb}$ \\
\hline \multicolumn{2}{|c|}{$\Delta \mathrm{H}^{\mathrm{o}}, \mathrm{kJ} / \mathrm{mol}$} & 20.04 & 18.87 \\
\hline \multicolumn{2}{|c|}{$\Delta \mathrm{S}^{\mathrm{o}}, \mathrm{J} / \mathrm{mol} \mathrm{K}$} & 91 & 75 \\
\hline \multirow{3}{*}{$\begin{array}{c}\Delta \mathrm{G}^{\mathrm{o}}, \\
\mathrm{kJ} / \mathrm{mol}\end{array}$} & $298 \mathrm{k}$ & -6.78 & -3.48 \\
\cline { 2 - 4 } & $308 \mathrm{k}$ & -7.68 & -4.23 \\
\cline { 2 - 4 } & $318 \mathrm{k}$ & -8.58 & -4.98 \\
\cline { 2 - 4 } & $328 \mathrm{k}$ & -9.48 & -5.73 \\
\hline \multicolumn{2}{|c|}{$\mathrm{R}^{2}$} & 0.94 & 0.95 \\
\hline
\end{tabular}

In this study, Effective adsorbent was prepared Muscovite by activation with $\mathrm{H}_{2} \mathrm{O}_{2}, \mathrm{HCl}$ and/or $\mathrm{H}_{2} \mathrm{O}_{2} / \mathrm{HCl}$, in which the most effective activator for the removal of $\mathrm{Pb}$ and $\mathrm{Cd}$ was $\mathrm{H}_{2} \mathrm{O}_{2} / \mathrm{HCl}$. The results of batch $\mathrm{Pb}$ and $\mathrm{Cd}$ adsorption experimental studies reflected that the adsorption operation depends on $\mathrm{pH}$, contact time, adsorbent dose, intial metal concentration, and solution temperature. The adsorption kinetics of lead and cadmium ions followed the pseudo secondorder kinetic model. The linearadsption isotherms models were used to represent the experimental data, and the Langmuir model fitted well the metal adsorption. The negative value of $\Delta \mathrm{G}^{\mathrm{o}}$ and $\Delta \mathrm{S}^{\mathrm{O}}$ showed that the adsorption of the lead and cadmium ions by Muscovite adsorbent. The simple, clean, and green procedure of this adsorbent would offer a vital technique for industrial wastewater cleanup.

\section{References}

Abollino O. , A.Giacomino, M.Malandrino, E.Mentasti (2008) Interaction of metal ions with montmorillonite and vermiculite . Applied Clay Science, 38(3-4) 227-236

Adekunle A.S., J.A.O. Oyekule, S.O. Baruwa, O.A. Ogunfowokan, E.E. Ebenso (2014) Speciation Study of the heavy metals in commercially available recharge cards coatings in Nigeria and the health implications, Toxicol. Rep. 1, 243-251.

Badawy, N.A., El-Bayaa, A.A., AlKhalik, E.A. (2010). Vermiculite as an exchanger for copper(II) and $\mathrm{Cr}$ (III) ions, kinetic studies. Ionics 16, 733-739.

Cheira M. F., Mohamed N. Rashed, Adila E. Mohamed, Ibrahim H. Zidan, Mohamed A. Awadallah (2019) Removal of some harmful metal ions from wet-process phosphoric acid using murexide-reinforced activated bentonite. Materials Today Chemistry 14 , 100176. DOI:/10.1016/j.mtchem.2019.06.002.

Cheira M. F.,, Mohamed N. Rashed, Adila E. Mohamed, Ibrahim H. Zidan , Mohamed A. Awadallah (2019) .The performance of Alizarin impregnated bentonite for the displacement of some heavy metals ions from the wet phosphoric acid, Separation Science and Technology, DOI: 10.1080/01496395.2019.1675701. 
Chen A. H., Liu S. C., Chen C.Y. and Chen C. Y. (2008). Comparative adsorption of Cu(II), $\mathrm{Zn}$ (II) and $\mathrm{Pb}$ (II) ions in aqueous solution on the crosslinked chitosan with epichlorohydrin, J. Hazard. Mater. 154, 184-191.

Chowdhury S. and Saha P. (2010). Sea shell powder as a new adsorbent to remove Basic Green 4 (Malachite Green) from aqueous solutions: Equilibrium, kinetic and thermodynamic studies, Chemical Engineering Journal, 164, 168-177.

Dabrowski A. (2001). Adsorption from theory to practice, Adv. Colloid Interface Sci. 93, 135224.

Eftekhari S., Habibi-Yangjeh A., Sohrabnezhad S. (2010). Application of AlMCM-41 for competitive adsorption of methylene blue and Rhodamine B: Thermodynamic and kinetic studies, J. Hazard. Mater. 178, 349-355.

El-Bayaa, A.A.; Badawy, N.A.; AlKhalik, E.A.( 2009). Effect of ionic strength on the adsorption of copper and chromiumions by vermiculite pure claymineral. J. Hazard.Mater. 170, 12041209

Erdem E., N. Karapinar, R. Donat. (2004) The removal of heavy metal cations by natural zeolites .Journal of Colloid and Interface Science 280, 309-314

Gadd, G.M. (1988) Accumulation of metals by microorganisms and algae, in: H.-J. Rehm (Ed.), Biotechnology, VCH, Weinheim, pp. 401-433.

Gerçel Ö., F.H. Gerçel (2007) Adsorption of lead(II) ions from aqueous solutions by activated carbon prepared from biomass plant material of Euphorbia rigida, Chem. Eng. J. 132 (1-3), 289-297.

Gunay A., Arslankaya E. and I. Tosun (2007). Lead removal from aqueous solution by natural and pretreated clinoptilolite: adsorption equilibrium and kinetics, J. Hazard. Mater. 146, $362-371$.

Hashem. F.S,Amin. M.S, El-Gamal. S.M.A. (2015) Chemical activation of vermiculite to produce highly efficient material for $\mathrm{Pb} 2+$ and $\mathrm{Cd} 2+$ removal, Applied Clay Science, 115 ,189-200

Hamidpour M, Karamooz M, Akhgar A, Tajabadipour A, Furrer G.( 2019). Adsorption of cadmium and zinc onto micaceous minerals: Effect of siderophore desferrioxamine B. Pedosphere. 29(5): 590-597.

Inbaraj B. S. and Sulochana N. (2006). Use of Jackfruit Peel Carbon for adsorption of Rhodamine B, a basic dye from aqueous solution, Indian Journal of Chemical Technology, $13,17-23$.

Ismail Nor HafizahChe, Nur Suraya AnisAhmad Bakhtiar, HazizanMd. Akil (2017). Effects of cetyltrimethylammonium bromide (CTAB) on the structural characteristic of nonexpandable muscovite. Materials Chemistry and Physics 196, 324-332.

Kamal S., Ahmed F. E., Hussein F. G., Shokry G. E. B. and Mamdoh R. (2010). Removal of rhodamine B (a basic dye) and thoron (an acidic dye) from dilute aqueous solutions and wastewater simulants by ion flotation, Water Research 44, 1449-1461. 
Katsou E, Malamis S, Tzanoudaki M, Haralambous KJ, Loizidou M (2011) Regeneration of natural zeolite polluted by lead and zinc in wastewater treatment systems. J Hazard Mater 189:773-786

Mahdavi, S., Jalali, M., Afkhami, A.( 2013). Heavy metals removal from aqueous solutions using $\mathrm{TiO} 2, \mathrm{MgO}$, and Al2O3 nanoparticles. Chem. Eng. Commun. 200, 448-470

Muazu N. D., Alaadin Bukhari, Khaled Munef (2020) Effect of montmorillonite content in natural Saudi Arabian clay on its adsorptive performance for single aqueous uptake of $\mathrm{Cu}(\mathrm{II})$ and Ni(II). Journal of King Saud University - Science 32 , 412-422

Nollet Hendrik, Murielle Roels, Pierre Lutgen, Paul Van der Meeren , Willy Verstraete (2003). Removal of PCBs from wastewater using fly ash, Chemosphere 53, 655-665.

O'Connell, D.W., Birkinshaw, C., O'Dwyer, T.F( 2008). Heavy metal adsorbents prepared from the modification of cellulose: a review. Bioresour. Technol. 99, 6709-6724.

Ozcan Adnan, Mine Oncu and Safa Ozcan (2006). Kinetics, isotherm and thermodynamic studies of adsorption of Acid Blue 193 from aqueous solutions onto natural sepiolite, Colloids and Surfaces A: Physicochemical and Engineering Aspects 277, (1-3), 90-97.

Pagliuca A., G.J. Mufti, (1990) Lead poisoning: an age-old problem, Br. Med. J. 300, 830

Puranik P.R., K.M. Paknikar (1997) Biosorption of lead and zinc from solutions using Streptoverticillium cinnamoneum waste biomass, J. Biotechnol. 55 (2), 113-124.

Rashed M.Nageeb, A. Rashed Mohamed, M. Ahmed Awadallah (2017).Preparation of adsorbent from phosphate rock waste to be used for the removal of heavy metals from wastewater. Journal of Applied Chemistry Science . Journal of Applied Chemical Science International, 10(1), 22-35.

Rashed M.Nageeb, Mohamed E. Soltan, Mahasen M. Ahmed, Ahmed N. E. Abdou (2018) Heavy Metals Removal from Wastewater by Adsorption on Modified Physically Activated Sewage Sludge. Archives of Organic and Inorganic Chemical Sciences, 1(1), 1-8.

Rashed Mohamed Nageeb, Allia Abd-Elmenaim Gad, Nada Magdy Fathy (2019). Adsorption of $\mathrm{Cd}$ (II) and $\mathrm{Pb}$ (II) Using Physically Pretreated Camel Bone Biochar. Advanced Journal of Chemistry-Section A, 2(4), 347-364

Sander J.T. Brugman, Ben L. Werkhoven, Eleanor R. Townsend, Paolo Accordini, René van Roij, Elias Vlieg Monovalent (2020) divalent cation competition at the muscovite mica surface: Experiment and theory / Journal of Colloid and Interface Science 559 , 291-303

Schmidt M., S.S. Lee, R.E. Wilson, L. Soderholm, P. Fenter(2012) Sorption of tetravalent thorium on muscovite. Geochimica et Cosmochimica Acta 88, 66-76.

Shawky Ahmed, Said El-Sheikh,Mohamed Nageeb Rashed, Thanaa I. El Dosoqy, Sabrin.Abdo (2019). Exfoliated kaolinite nanolayers as an alternative photocatalystwith superb activity. Journal of Environmental Chemical Engineering,7(3),103174.

Sis Hikmet, Turan Uysal (2014) Removal of heavy metal ions from aqueous medium using Kuluncak(Malatya) vermiculites and effect of precipitation on removal. Applied Clay Science $95,1-8$ 
Sivakumar P. and Palanisamy P. N. (2011). Non-conventional low-coast adsorbent from Euphorbia antiquorum $\mathrm{L}$ for the removal of direct blue 53 from its aqueous solution, Indian Journal of Chemical Technology, 18, 188-196.

Wu, X., Zhao, F., Chen, M., Zhang, Y., Zhao, C., Zhou, H.( 2008). Factors affecting the adsorption of $\mathrm{Zn} 2+$ and $\mathrm{Cd} 2+$ ions from aqueous solution onto vermiculite. Adsorpt. Sci.

Technol. 26, 145-155.

Yang Jung-Seok, Ju Young Lee, Young-Tae Park, Kitae Baek \& Jaeyoung Choi (2010) Adsorption of $\mathrm{As}(\mathrm{III}), \mathrm{As}(\mathrm{V}), \mathrm{Cd}(\mathrm{II}), \mathrm{Cu}(\mathrm{II})$, and $\mathrm{Pb}$ (II) from Aqueous Solutions by Natural Muscovite, Separation Science and Technology, 45:6,814-823 